\title{
Strategies for Maintaining Tax Compliance of SMEs During Covid-19 \\ Pandemic by Using Supply Chain Management Integration Approach
}

\author{
Aramia Fahriyah ${ }^{1}$, Wuwuh Andayani ${ }^{2}$, Rochland Yoseph ${ }^{3}$, \\ S. Penta Nurwibowo ${ }^{4}$, Wendy Irawan ${ }^{5}$ \\ ${ }^{12345}$ Institut Ilmu Sosial dan Manajemen STIAMI \\ Correspondent: aramia.stiamli@gmail.com ${ }^{1}$
}

\begin{abstract}
Received : August 26, 2021
Accepted : January 15, 2022

Published : January 31, 2022
\end{abstract}

Citation: Fahriyah, A., Andayani, W., Yoseph R., Nurwibowo, S, P., Irawan, W. (2022). Strategies for Maintaining Tax Compliance of SMEs During Covid-19 Pandemic by Using Supply Chain Management Integration Approach. Ilomata International Journal of Tax \& Accounting.3(1), 57-67. https://doi.org/10.52728/ijtc.v4i1.409

\begin{abstract}
The new normal life of Covid-19 pandemic has brought a new life pattern which is more strict health protocols in the interaction among each other. In the normal time, although the level of tax revenue shows a rising trend, the tax ratio hasn't shown any significant increase. Also, it is still left behind other developing countries. Related to the pandemic effect, the world economy is decreasing and resulting to the decline of the Indonesian tax revenue. The concerns of this study are on how to optimize the compliance level of tax payment from Small-Medium Sized Enterprises (SMEs) and the efforts of optimization needed to be done including in helping SMEs for being able to survive and or to be improved in terms of its business performance. Thus, they can contribute to maintaining their tax compliance at the same time from getting worse. This study employed a descriptive research method using a qualitative approach. The data sources were primary and secondary data. In this study, an operational management tool which is the approach of Supply Chain Management (SCM) integration will be implemented as the solution. It is found that the gradual application of the concept of SCM integration will give several significant impacts on the SMEs' performance including their compliance with the existed tax regulations. Also, this will encourage the optimal taxation authority in managing the tax participation of the SMEs sector.
\end{abstract}

Keywords: tax compliance, SMEs, new normal, Supply Chain Management (SCM) integration

\section{INTRODUCTION}

In the current pandemic era, people were directed to live the New Normal life. This is a new life pattern completed with more strict health protocols in the interaction among each other. Related to the business situation, the effect of pandemic needs to be anticipated and dealt with as it can prevent the decline of a business or it can even strive for improvement. One of the business areas is Small-Medium Sized Enterprises (SMEs) (Bai et al., 2021). SMEs are businesses that maintain revenues, assets, or some employees below a certain threshold (Perdana et al., 2021). Although it is small in size, SMEs play an important role in a country's economy, particularly in developing countries. Then, SMEs also consider the majority of businesses worldwide and are crucial 


\section{Strategies for Maintaining Tax Compliance of SMEs During Covid-19 Pandemic by Using Supply Chain Management Integration Approach \\ Fahriyah, Andayani, Yoseph, Nurwibowo, Irawan}

contributors to job vacancies and global economic development (․ Dai et al., 2021). They represent about $90 \%$ of businesses and more than $50 \%$ of employment worldwide. Formal SMEs contribute national income (GDP) in emerging economies up to $40 \%$. These numbers are significantly higher when informal SMEs are included (Shafi et al., 2020).

About 57 million MSMEs (Micro-Small-Medium Sized Enterprises) were operating in Indonesia in 2017 (Tambunan, 2019). About 97 percent of the total workforce is currently employed in MSMEs, while 99.9 percent of all businesses in Indonesia are MSMEs. MSMEs account for approximately 60 percent of the overall GDP of Indonesia. For the details, overall GDP of Indonesia (in \%): Micro 30\%, Small 13\%, Medium 15\%, and Cooperative 23\%. Here, it can be concluded that Small-Medium Sized Enterprises provide about $28 \%$ of the total Indonesian GDP (Susanti \& Widajatun, 2021).

As one of the fundamental country's incomes, SMEs contribute to the country's economy in terms of its tax. Based on the data from the Tax Office; for SMEs, the PPH final is $0.5 \%$. It is written in UU No 36 of the year 2008. It is addressed for SMEs which get profits fewer than 4.8 billion. Therefore, normally, the SMEs only need to pay $0.5 \%$ of their income. Many SMEs did not pay regularly for their tax, so it seems that the tax revenue from SMEs had not reached the target (Malahayati et al., 2021; Shafi et al., 2020).

Nowadays, since the pandemic of COVID-19 has happened, Indonesian tax revenue, especially from SMEs was more and more not optimal. It is found that there were some challenges appeared. First, most SMEs lacked education and understanding of tax policies. Psychologically, they were afraid of going to the tax office for any business or even joining any tax meeting held by the tax authority. It showed that there was a problem of misunderstanding by SMEs towards tax authority. They mostly thought that all business related to the tax authority will be related to the payment they must pay. Second, SMEs' income is currently decreasing. As the New Normal life made citizens take a distance from each other, they rarely go outside and buy something directly. As the result, it made the cash flow of SMEs also decreases. Last, there are still many opportunities for improvements in our Indonesian tax authority, like having more education and socialization agenda for SMEs in more different and interesting ways (Trinh et al., 2020).

Based on the previous research, tax compliance was influenced by taxpayer's knowledge, transparency of state spending, and tax justice. While supply chain management builds upon the flow of products and information through an operation and seeks to achieve linkage and co-ordination between the processes of other entities in the pipeline. The focus of supply chain management is on co-operation and trust and the recognition that, properly managed, the 'whole can be greater than the sum of its parts. Thus, the Supply Chain Management approach will improve any related factors above which improve tax compliance (Allen et al., 2021; Beske et al., 2014).

To deal with the matters explained before, this study tried to solve it by using an operational management tool which is the approach of Supply Chain Management (SCM) integration. The SCM integration will connect all parties involved with the fulfillment of the goal into a single system. The parties involved may include SMEs, tax authorities (government), citizens, educational institutions, etc. It is hoped that all of them will work together effectively to pursue the same goal. Therefore, when the gradual application of SCM integration is used, it will give several significant impacts on the SMEs' performance including their compliance with the existed tax regulations. Moreover, this will encourage the optimal taxation authority in managing the tax participation of the SMEs sector (Centobelli et al., 2021; Zhang et al., 2021). 


\section{METHOD}

A descriptive approach was applied in this study. It was implemented by drawing a conclusion from some collected research and using a method of qualitative normative analysis. Normative means using secondary data as the resources, including theories and opinions from scholars and well-known experts. Next, qualitative means that it is a process of data analysis without using any formulas and numbers coming from the information of literature studies (data collected either from the related institutions or from research observation which was done) (Sugiyono, 2019).

The research methodology could cover the following points: (1) A concise explanation of the research methodology is prevalent; (2) reasons to choose particular methods are well described; (3) research design is accurate; (4) the sample design is appropriate; (5) data collection processes are proper; and (6) data analysis methods are relevant and state-of-the-art. (

\section{RESULT AND DISCUSSION}

\section{A. The business situation of SMEs during the Covid19 outbreak and its implications}

The increase in countries affected by the Covid-19 virus around the world has made the world economic situation worse. Some institutions even predicted the weakening of the world economy, including the International Monetary Fund (IMF) which projects a global economy to grow minus at 3\%. Minister of Finance (Minister of Finance of the Republic of Indonesia) explained that State Revenue in March 2020 grew positively although then the Government was wary of the impact of the pandemic in the coming months (Stephens et al., 2021).

Along with the policy of Work From Home (WFH) for both the government and the private sector, a slowdown in business activity began at the end of March 2020 which has the potential to reduce domestic delivery reducing the receipt of Domestic Value Added Tax (PPN DN) in April 2020. This condition is likely to continue and become increasingly contracted in May. Then, in April some regions have implemented Large Scale Social Restrictions (PSBB) in several affected areas. In line with the implementation of the WFH and PSBB, the Government provides tax facilities in the form of relaxation of Article $29 \mathrm{PPh}$ OP payments and reporting of the $\mathrm{PPh} \mathrm{PP}$ SPT, which results in the non-optimal realization of the Article $29 \mathrm{PPh}$ OP revenue (Abubakar, 2021).

The Central Statistics Agency reported that the economic growth in the first quarter of 2020 reached $2.97 \%$ as the impact of the COVID-19 pandemic. This number was decreased compared to the first quarter of 2019 which was $5.07 \%$ year on year. The decline in economic growth has also impacted the micro, small and medium business (MSME) business in Indonesia. Here, according to the Ministry of Cooperatives and SMEs, the MSME opened $99.7 \%$ of employment in Indonesia in 2019 (Hanoatubun, 2020).

If it was calculated, the total number of SMEs in Indonesia currently reaches 59.2 million businesses. With the 40 percent figure, the UMKM that will stop operating reaches 23.68 million businesses. 


\section{Strategies for Maintaining Tax Compliance of SMEs During Covid-19 Pandemic by Using Supply Chain Management Integration Approach \\ Fahriyah, Andayani, Yoseph, Nurwibowo, Irawan}

"In April 2020, the survey resulted that 43 percent of MSMEs would stop operating. Then, there was a survey from the Faculty of Economics and Business at Padjadjaran University stating that the data was almost the same as 47 percent of MSMEs in West Java had stopped. If it is averaged with another survey, 40 percent of MSMEs will stop (Syaidah, 2020; Y Yusmar et al., 2021).

\section{B. Tax compliance Progress}

The economic downturn affected households, MSMEs, Corporations, and the Financial Sector. Thus, the SMEs were also being impacted with difficulties to run their business, then it has the probability of being disturbed to pay their credit obligation. Non-Performed Loan of banking credit can be increased significantly, so it will also worsen the economic condition (usan, 2020).

According to the Ministry of Finance of the Indonesian Government, they have been acting some actions to manage this pandemic crisis such us:

a. Design a Program of budget refocusing and reallocation, by President Law no 9/2020 (Source of Funding) and President Instruction No 4/2020 (implementation mechanism)

b. Release monetary stimulus

c. Release some State Financial Policies

Tax revenue is a major contributor to the state budget. Since 2009, the contribution of tax revenue is above $70 \%$ with an increasing trend. However, the tax ratio tends to be stagnant (between 11 $12 \%)$. It is relatively low compared to ASEAN, OECD, and Latin-Caribbean countries.

The Realization of State Revenues is derived from Taxation Revenue and Non-Tax State Revenues (PNBP) which has nominal amounted to Rp279.89 trillion and Rp95.99 trillion. Meanwhile, the realization of the grant in the same period only reached IDR0.08 trillion. The Tax Revenue and PNBP grew by $0.43 \%$ and $37 \%$ respectively.

Meanwhile, the overall growth of the Tax revenue component up to the end of March 2020 is still sourced from taxes on household consumption, although tax revenue is also still overshadowed by pressure due to the weakening trend in the manufacturing industry and international trade activities, as well as the weakening of economic activity due to the spread of Covid-19.

There was a slowdown in business activity at the end of March 2020 which has the potential to reduce Domestic Value Added Tax revenues. The government provides taxation facilities in the form of relaxation of PPh No OP 29 payments and OP PPh SPT reporting, which impact the non-optimal realization of income tax.

\section{SCM Integration}

Looking at what the Directorate General of Taxation (DGT) has done so far and the dynamics and performance of taxation in Indonesia from the data shared by DGT, here are some information stated:

- DGT Steps \& Strategies are good enough

- Optimization aspects of the strategies that have been implemented can be further refined, i.e. with the principle approach of Supply Chain Management Integration.

- The SME sector is also experiencing problems, while there are increasingly pressured, on the other hand, is the level of compliance with tax payments that are still low. This aspect also 
Strategies for Maintaining Tax Compliance of SMEs During Covid-19 Pandemic by Using Supply Chain Management Integration Approach

Fahriyah, Andayani, Yoseph, Nurwibowo, Irawan

needs to be deepened to get improvement on all of the related parties or in terms of the Indonesian Taxation SCM environment.

- As has been proven starting from the history of warfare, and companies that can get through a crisis well, use the principles of the Supply Chain Management approach in maximizing strategy and implementation.

From the implementation and dynamics of the tax so far as well as the data that has been submitted by DGT \& Ministry of RI, several SCM principles need to be implemented. Also, the implementation details can be adjusted in each of the points \& concerns as follows:

Indonesian Tax Share Holders must be in line with the greatest business environment challenge today, which is the integration (to achieve linkage \& co-ordination collaboratively) of supply chains between the processes of other entities in the pipeline and the organization itself to satisfy ultimate customers and obtain value for those companies (group chain)

\section{The supply chain and competitive performance}

Indonesia Tax Authority (DGT) stated that all Indonesian Tax Share Holder is integrated as the supply chain is the network, through upstream and downstream linkages. It is in the different processes and activities that produce value in the form of products and services in the hands of the ultimate consumer. Value is one of the important keys to perform the best performance of the Indonesia tax system. Here, it is an urgency to avoid traditional-style-organization who viewed itself as entities that exists independently from others. Indeed, they need to compete with other country's organization to survive. The real competition is not one entity against one other entity but rather supply chain against supply chain. Thus, internal integration itself is not sufficient $\underline{\mathrm{Hu}}$ et al., 2019; Turker \& Altuntas, 2014).

Supply chain management is a comprehensive system that can be approached by taking advantage of some leverage tools (Madhani, 2019). The DGT can take some of the leverage tools to optimize implementation of SCM such as:

- Collaboration with SCM experts to ensure the proper SCM managements

- Benchmarking into business environment who has an excellent performance by SCM improvement \& integration

- Make sure to do proper SCM standardization at all related aspects

\section{The changing competitive environment}

As the competitive context of business continues to change, bringing with its new complexities and concerns for management generally. It also has to be recognized that the impact on the Indonesian taxation system of these changes must be considerable. The challenges are perhaps the most pressing currently are:

- The new rules of competition

- Globalization of industry

- Downward pressure on price or economic consideration

- Customers taking control 
Strategies for Maintaining Tax Compliance of SMEs During Covid-19 Pandemic by Using Supply Chain Management Integration Approach

Fahriyah, Andayani, Yoseph, Nurwibowo, Irawan

In terms of the Indonesian Tax system, there were many changes and challenges such as:

- New economic era and globalization, while Indonesia on the warm economical competition with other country automatically bring out many challenges that tax authority must have update style to push this as a benefit for the country.

- In terms of SME people, DGT has some new and interesting policies to attract them. While DGT can't act as a single player, it must be collaborative work of socialization, especially to set some interesting value for citizen tax obligation and to make sure that the value is properly delivered.

- Give the citizen greater access to be involved in various ways of collaboration and work.

\section{The delivering customer value}

In this hard situation, the DGT must determine the level of customer value that is delivered in its chosen segment. The Indonesian Tax system is almost unique in its ability to impact both the numerator and the denominator of the customer value ratio. The ratio is as follows:

\begin{tabular}{|cc|}
\hline Customer value $=$ & Quality $\mathrm{x}$ Service \\
& -------------------- \\
& Cost $\times$ Time \\
\hline
\end{tabular}

Each of the four constituent elements can briefly be defined as follows:

- Quality: the functionality, performance, and technical performance of tax authority

- Service: the availability, support, and commitment provided to the customer.

- Cost: the customer's transaction costs or effort to comply with tax regulation

- Time: the time is taken to respond to customer requirements, e.g. delivery lead times.

Many Indonesian citizens didn't have a standard value perception of their tax obligation and compliance. Many of them have serious questions: "Why do we pay the tax? What for?". This is interesting homework and must be solved by an integrated and better approach to the taxpayer.

\section{Creating the responsive supply chain}

As being explained in some DGT release, there are some rooms for improvement. These positive findings need to be responded to ever increase the levels of volatility in demand.

To meet this challenge, the DGT needs to focus on its efforts upon achieving much greater agility. It can be responded to in shorter time-frames in terms of both volume change and variety change. Agility has many dimensions and the concept applies as much to networks as it does to individual companies. Indeed, a key to agile response is the presence of agile partners upstream and downstream of the focal firm such as academic entities.

\section{The era of network competition}

The Indonesian tax stakeholders can optimize the performance by implementing principles of logistics and supply chain management, to significantly in developing responsive logistics 
capability. The success in the operations is due to many things there that can be no doubting the role that logistics and supply chain management have played in achieving that success.

Based on an analysis of the leading companies in the survey, they have identified six consistent characteristics exhibited by those companies as follows:

a. Outside-in focus

DGT must consider from the customer backward and are demand-driven.

b. Embedded innovation

This implies a close integration between tax environment supply chain begins on the drawing board.

c. Extended supply chain

A recognition that today the close management of relationships from end-to-end is essential.

d. Balanced Metrics

To achieve high levels of agility and responsiveness, there has to be a realization that there will be trade-offs across the business. To achieve the best overall outcomes requires a set of key performance indicators (KPIs) that reflect the need for balance.

e. Attitude

A culture that extends across the organization based on the recognition that internal silos must be removed and that external relationships need to be managed in a spirit of partnership

f. Supply chain talent

As supply chains are as much about people as anything, the tax authority needs to ensure to develop the skills and capabilities that will enable success on the previous five elements. While there is a short key to perform this human resource challenge, through optimizing the benefit of certification to ensure the skill update.

\section{Integration}

As the integration of SCM is now the greatest challenge, the Indonesian tax system must ensure the effectiveness of chains devolves from how they are set up, incorporating the following ideas:

a. Pulling the chain together.

b. Chain performance measures (using the Balanced Scorecard and the SCOR Model).

c. Trade-offs. As there are complex interactions, in the process also should be designed and operated with suitable tradeoffs between processes, movements, and stocks along the chain.

\section{Overcoming the barriers to supply chain integration}

On the operation management aspects, the conventional organization poses an immediate problem. Tax entities should avoid a functional basis.

\section{Creating a sustainable supply chain}

The definition of sustainability is most widely used originally from the United Nations Brundtland Commission, which reported in 1987. Sustainability, the Commission suggested, was about meeting the needs of the present without compromising the ability of future generations to meet their own needs (Kouhizadeh et al., 2021; Vural et al., 2021). 


\section{Strategies for Maintaining Tax Compliance of SMEs During Covid-19 Pandemic by Using Supply Chain Management Integration Approach}

Fahriyah, Andayani, Yoseph, Nurwibowo, Irawan

The triple bottom lines.

The triple bottom line concept emphasizes the importance of examining the impact of business decisions on three key areas:

a. Environment (e.g. pollution; climate change; the depletion of scarce resources, etc.)

b. Economy (e.g. effect on people's livelihoods and financial security; profitability of the business, etc.)

c. Society (e.g. poverty reduction; improvement of working and living conditions, etc.).

\section{Figure 13.1 The triple bottom line: planet, people, profit}

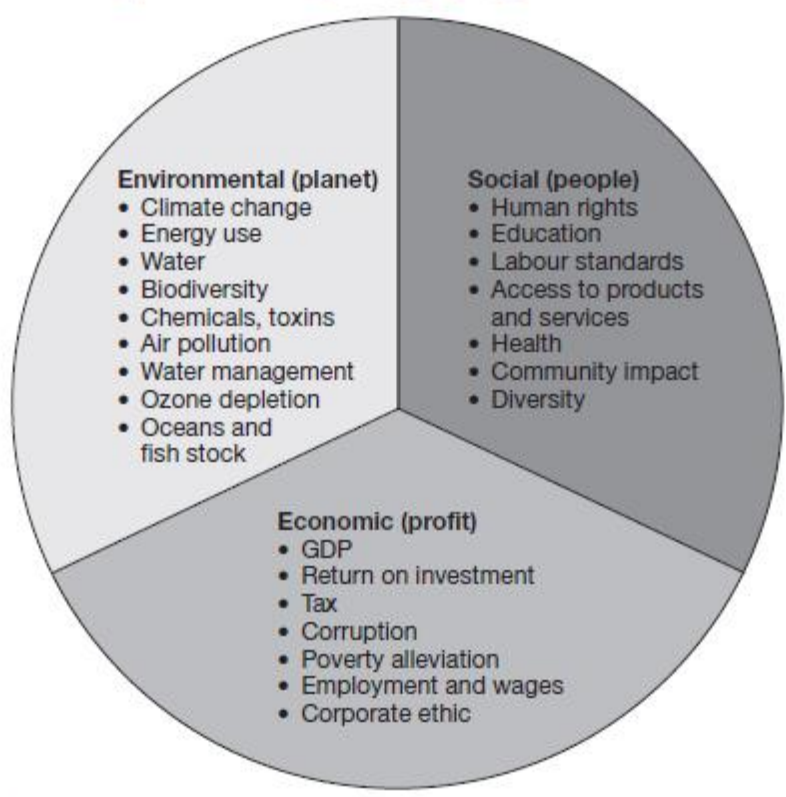

Source: Accenture

These three elements - the 3Ps of people, profit, and planet - are inevitably intertwined and they serve to remind us that for a business to be truly sustainable, and these basic principles also need to be implemented on the background of the Indonesia Tax System.

In the context of SCM, based on the United Nations Brundtland Commission, a triple bottom line philosophy can be built to encompass the broader idea that sustainability is concerned with ensuring the long-term viability and viability of the business as well as contributing to the future well-being of society (I. Dai et al., 2021; Jabbour et al., 2020). Indeed, it can be argued that these two objectives are mutually reinforcing, i.e. supply chain strategies that benefit the wider environment are likely to also involve businesses at lower costs in the long run as a result of better use of resources (Christopher \& Peck, 2012; Soltanmohammadi et al., 2021).

As supply chains underpin the efficiency and effectiveness of businesses, they can provide a useful framework for exploring opportunities to improve sustainability. We need to understand the sustainability impact of everything we do start from product design to end-of-life disposal. Here, related to the tax compliance, as the emphasis of SCM is on co-operation and trust, automatically it will influence the taxpayers' awareness on the punctuality and regularity on paying the tax (Rahayu, 2019). 


\section{CONCLUSION}

The conclusions of this research were as follows:

1. Nowadays, the Indonesia Tax System faces a difficult situation, as well as in the business environment they also experience several times facing the hard situation. The Logistic or Supply Chain Management Integration principle has been proven many times as a problem solver in those challenges.

2. Supply chain management doesn't provide the fixed recipe, yet it provides wide and flexible tools to manage any circumstances and also better performance through their competitive advantage.

3. The Indonesian taxation system in SCM views still has a lot of room for improvement, so the DGT and government have an opportunity to get SCM advantage who has a complete and flexible approach to performing operational excellent within the chain:

a. To maintain the degree of Indonesian citizen tax compliance, especially by the better tax matters understanding \& proper tax environment.

b. To build SME endurance to fight the pandemic

c. DGT has flexibility \& operational excellent to perform the best Indonesia tax system environment

4. The impact of the environment that properly and continuously perform SCM Integration is the ability to provide excellent result and good endurance to fight difficult situation.

Then, it is recommended that; first; tax agencies should assign specialized bodies for the comprehensive implementation of SCM approach and follow-up the taxpayers who paid lately. Second, some simple systems of payment and facilitators should be provided to facilitate the taxpayers who are lack of knowledge. Last, voluntary compliance of taxpayers should be facilitated.

\section{REFERENCE}

Abubakar, R. W. A. (2021). Analisis Kebijakan Pemerintah Jawa Barat di Masa Pandemi Covid19 Dalam Perspektif Ekonomi. Aksyana: Jurnal Akuntansi Dan Keuangan Islam, 1(1), 96. https://doi.org/10.35194/ajaki.v1i1.1692

Allen, S. D., Zhu, Q., \& Sarkis, J. (2021). Expanding conceptual boundaries of the sustainable supply chain management and circular economy nexus. Cleaner Logistics and Supply Chain, 2, 100011. https://doi.org/10.1016/j.clscn.2021.100011

Bai, C., Quayson, M., \& Sarkis, J. (2021). COVID-19 pandemic digitization lessons for sustainable development of micro-and small- enterprises. Sustainable Production and Consumption, 27, 1989-2001. https://doi.org/10.1016/j.spc.2021.04.035

Beske, P., Land, A., \& Seuring, S. (2014). Sustainable supply chain management practices and dynamic capabilities in the food industry: A critical analysis of the literature. International Journal of Production Economics, 152, 131-143. https://doi.org/10.1016/j.ijpe.2013.12.026

Centobelli, P., Cerchione, R., Esposito, E., Passaro, R., \& Shashi. (2021). Determinants of the transition towards circular economy in SMEs: A sustainable supply chain management perspective. International Journal of Production Economics, 242, 108297. https://doi.org/10.1016/j.ijpe.2021.108297

Christopher, M., \& Peck, H. (2012). Marketing Logistics (Butterworth-Heinemann (ed.); 2nd ed.). Routledge. https://doi.org/10.4324/9780080496429 
Strategies for Maintaining Tax Compliance of SMEs During Covid-19 Pandemic by Using Supply Chain Management Integration Approach

Fahriyah, Andayani, Yoseph, Nurwibowo, Irawan

Dai, J., Xie, L., \& Chu, Z. (2021). Developing sustainable supply chain management: The interplay of institutional pressures and sustainability capabilities. Sustainable Production and Consumption, 28, 254-268. https://doi.org/10.1016/j.spc.2021.04.017

Dai, R., Feng, H., Hu, J., Jin, Q., Li, H., Wang, R., Wang, R., Xu, L., \& Zhang, X. (2021). The impact of COVID-19 on small and medium-sized enterprises (SMEs): Evidence from twowave phone surveys in China. China Economic Review, 67, 101607. https://doi.org/10.1016/j.chieco.2021.101607

Hanoatubun, S. (2020). Dampak Covid - 19 terhadap Prekonomian Indonesia. EduPsyCouns: Journal of Education, Psychology and Counseling, 2(1), 146-153. https://ummaspul.ejournal.id/Edupsycouns/article/view/423

Hashimov, E. (2015). Qualitative Data Analysis: A Methods Sourcebook and The Coding Manual for Qualitative Researchers. Technical Communication Quarterly, 24(1), 109-112. https://doi.org/10.1080/10572252.2015.975966

Hu, J., Liu, Y.-L., Yuen, T. W. W., Lim, M. K., \& Hu, J. (2019). Do green practices really attract customers? The sharing economy from the sustainable supply chain management perspective. Resources, Conservation and Recycling, 149, 177-187. https://doi.org/10.1016/j.resconrec.2019.05.042

Jabbour, C. J. C., Fiorini, P. D. C., Ndubisi, N. O., Queiroz, M. M., \& Piato, É. L. (2020). Digitally-enabled sustainable supply chains in the 21st century: A review and a research agenda. Science of The Total Environment, 725(138177), $1=14$. https://doi.org/10.1016/j.scitotenv.2020.138177

Kouhizadeh, M., Saberi, S., \& Sarkis, J. (2021). Blockchain technology and the sustainable supply chain: Theoretically exploring adoption barriers. International Journal of Production Economics, 231, 107831. https://doi.org/10.1016/j.ijpe.2020.107831

Madhani, P. M. (2019). Building a Customer-Centric Supply Chain Strategy: Enhancing Competitive Advantages. Journal of Business Strategy IUP, 16(2), 28-42. https://www.researchgate.net/publication/334611456_Building_a_CustomerCentric_Supply_Chain_Strategy_Enhancing_Competitive_Advantages

Malahayati, M., Masui, T., \& Anggraeni, L. (2021). An assessment of the short-term impact of COVID-19 on economics and the environment: A case study of Indonesia. EconomiA. https://doi.org/10.1016/j.econ.2021.12.003

Perdana, A., Lee, H. H., Koh, S., \& Arisandi, D. (2021). Data analytics in small and mid-size enterprises: Enablers and inhibitors for business value and firm performance. International Journal of Accounting Information Systems, 100547. https://doi.org/10.1016/j.accinf.2021.100547

Rahayu, D. P. (2019). Faktor-faktor yang Mempengaruhi Kepatuhan Sukarela Wajib Pajak. Jurnal Akuntansi Indonesia, 8(1), 17. https://doi.org/10.30659/jai.8.1.17-25

Shafi, M., Liu, J., \& Ren, W. (2020). Impact of COVID-19 pandemic on micro, small, and medium-sized Enterprises operating in Pakistan. Research in Globalization, 2, 100018. https://doi.org/10.1016/j.resglo.2020.100018

Soltanmohammadi, A., Andalib Ardakani, D., Dion, P. A., \& Hettiarachchi, B. D. (2021). Employing total quality practices in sustainable supply chain management. Sustainable Production and Consumption, 28, 953-968. https://doi.org/10.1016/j.spc.2021.07.013

Stephens, S., McLaughlin, C., \& McLaughlin, K. (2021). Small business in a time of crisis: A five stage model of business grief. Journal of Business Venturing Insights, 16, e00282. https://doi.org/10.1016/j.jbvi.2021.e00282 
Strategies for Maintaining Tax Compliance of SMEs During Covid-19 Pandemic by Using Supply Chain Management Integration Approach

Fahriyah, Andayani, Yoseph, Nurwibowo, Irawan

Sugiyono. (2019). Metode Penelitian Kuantitatif Kualitatif dan R\&D (I). Alfabeta. https://cvalfabeta.com/product/metode-penelitian-kuantitatif-kualitatif-dan-rd-mpkk/

Susan, M. (2020). Financial Literacy and Growth of Micro, Small, and Medium Enterprises in West Java, Indonesia (pp. 39-48). https://doi.org/10.1108/S1571-038620200000027004

Susanti, N., \& Widajatun, V. W. (2021). MSMEs Understanding of Taxation During the COVID-19 Pandemic. Journal of Innovation and Community Engagement, 2(1), 35-46. https://doi.org/10.28932/jice.v2i1.3689

Syaidah. (2020). Inovasi Layanan Publik Pusat Informasi dan Koordinasi Jawa Barat (Pikobar) Saat Pandemi Covid-19. Jurnal Ilmu Komunikasi Dialektika UNLA Bandung, 7(2), 148-158. http://journal.unla.ac.id/index.php/dialektika/article/view/1730

Tambunan, T. T. H. (2019). Micro and Small Industries and the Use of Internet: Findings from Indonesian. Jurnal Ekonomi Indonesia, 8(2), 203-224. https://doi.org/10.52813/jei.v8i2.20

Trinh, Q. L., Morgan, P. J., \& Sonobe, T. (2020). Investment behavior of MSMEs during the downturn periods: Empirical evidence from Vietnam. Emerging Markets Review, 45, 100739. https://doi.org/10.1016/j.ememar.2020.100739

Turker, D., \& Altuntas, C. (2014). Sustainable supply chain management in the fast fashion industry: An analysis of corporate reports. European Management Journal, 32(5), 837-849. https://doi.org/10.1016/j.emj.2014.02.001

Vural, C. A., Baştuğ, S., \& Gülmez, S. (2021). Sustainable brand positioning by container shipping firms: Evidence from social media communications. Transportation Research Part D: Transport and Environment, 97, 102938. https://doi.org/10.1016/j.trd.2021.102938

Yusmar, A., Pambudi, A., Wibowo, H., Ningsih, L., Siregar, S. S., \& Asfarian, A. (2021). Perbandingan Provinsi Jawa Barat dan Provinsi DKI Jakarta Dalam Pemanfaatan Sistem Informasi Penanganan Covid-19. Jurnal Dialektika Informatika (DETIKA) Universitas Muria Kudus, 1(2), 38-43. https://doi.org/10.24176/detika.v1i2.5853

Zhang, J., Yalcin, M. G., \& Hales, D. N. (2021). Elements of paradoxes in supply chain management literature: A systematic literature review. International Journal of Production Economics, 232, 107928. https://doi.org/10.1016/j.ijpe.2020.107928 